\title{
Mitigation of adverse effects of salinity stress on sunflower plant (Helianthus annuus L.) by exogenous application of chitosan
}

\author{
Gehan Shaker Bakhoum ${ }^{1} \mathbb{D}$, Mervat Shamoon Sadak ${ }^{2^{*}}$ and Elham Abd El Moneim Badr ${ }^{1}$
}

\begin{abstract}
Background: Most developing countries are suffering from a decline in agricultural area and fresh water supply due to the adverse effects of climate change. Sunflower has been considered as having the ability to grow under various environmental conditions, tolerating levels considered stresses to other plants.

Materials and Methods: Thus, two field experiments were conducted in the screen of National Research Centre during two successive summer seasons 2018 and 2019, respectively to investigate the effect of soaking seeds of sunflower plant in different concentrations of chitosan (control, 25, 50 and $75 \mathrm{mg} / \mathrm{L}$ ) on growth, some physiological parameters, yield and its components and some chemical composition of the yielded seeds of sunflower under different salinity levels (control, 4000 and $8000 \mathrm{mg} /$ )).

Results: The obtained results showed that salt stress with $4000 \mathrm{mg} / \mathrm{L}$ recorded the highest values of all the studied growth characters, photosynthetic pigments, some physiological aspects, seed yield/plant and oil \%. On the other hand, the highest values of head diameter, head circumference, weight 50 seed and crude protein were obtained by control treatment. Meanwhile, the highest values of proline and free amino acid were recorded under higher salinity level $(8000 \mathrm{mg} / \mathrm{L})$. On the other hand, all chitosan treatments significantly enhanced growth and productivity of sunflower plant. Also, the obtained data that, chitosan concentration $(50 \mathrm{mg} / \mathrm{L})$ recorded the highest values of all the studied growth and yield quantity and quality via enhancing photosynthetic pigments and the studied physiological aspects, as compared with other treatments. As for interaction effect, plants treated with chitosan concentration (50 $\mathrm{mg} / \mathrm{L})$ under salinity level $(4000 \mathrm{mg} / \mathrm{L})$ recorded the highest growth characters, photosynthetic pigments and IAA. While the interaction between chitosan concentrations $(50 \mathrm{mg} / \mathrm{L})$ under salinity level $(8000 \mathrm{mg} / \mathrm{L})$ recorded the highest yield characters, except for crude protein ( $75 \mathrm{mg} / \mathrm{L}$ chitosan) in control plants (those plants irrigated with tap water).

Conclusion: In conclusion, chitosan treatments did not only improve plant growth and productivity but also could enhance the reducing effects of salinity stress on growth and productivity of sunflower plant. The most effective concentrations was $50 \mathrm{mg} / \mathrm{L}$ on increasing growth and yield of sunflower plant.
\end{abstract}

Keywords: Sunflower, Chitosan, IAA, Salt stress, Growth, Oil and protein, Osmoprotectants, Yield

\footnotetext{
* Correspondence: mervat_sh24@yahoo.com

${ }^{2}$ Botany Department, Agricultural and Biological Research Division, National

Research Centre, 33th El Behooth St., P.O. 12622, Giza, Egypt

Full list of author information is available at the end of the article
}

Springer Open (c) The Author(s). 2020 Open Access This article is licensed under a Creative Commons Attribution 4.0 International License, which permits use, sharing, adaptation, distribution and reproduction in any medium or format, as long as you give appropriate credit to the original author(s) and the source, provide a link to the Creative Commons licence, and indicate if changes were made. The images or other third party material in this article are included in the article's Creative Commons licence, unless indicated otherwise in a credit line to the material. If material is not included in the article's Creative Commons licence and your intended use is not permitted by statutory regulation or exceeds the permitted use, you will need to obtain permission directly from the copyright holder. To view a copy of this licence, visit http://creativecommons.org/licenses/by/4.0/. 


\section{Introduction}

Agricultural soils around the world are increasingly decreased by overpopulation, a biotic stresses, ever increasing natural disasters and global climate changes (Hasanuzzaman et al., 2013). Salt-affected lands area about 831 million hectares (ha) including 434 million ha and 397 million ha of sodic and saline soils (FAO 2000). More than 45 million ha of irrigated soil are salinity affected that account $20 \%$ of soil and 1.5 million ha of soil are out of cultivation each year owing to increased salinity levels (Pitman and Lauchli, 2002 and Mumns and Tester, 2008), if it continues in such way, $50 \%$ of agricultural soils can be lost by the middle of the twenty-first century (Mahajan and Tuteja, 2005). Salinity might be resulted by natural reasons (as weathering, precipitation of sea salt carried by wind and rain, etc.) in addition to, human activities as increased irrigation by underground water, saline water, poor drainage, etc. (Hasanuzzaman et al. 2013, Munns, 2005 and Manchanda and Garg, 2008). High levels of saline adversely affect on germination, plant growth, and reproducibility via adverse effects on different metabolic activities as photosynthesis, respiration, transpiration, membrane properties, nutrient balance, enzymatic activities, cellular homeostasis, and hormone balance. Thus cause over accumulation of reactive oxygen species (ROS); and in severe stress, it cause plant death (Mahajan and Tuteja 2005 and Hasanuzzaman et al. 2012). Plant could alleviate the adverse effect of salinity stress through decreasing salt content, ion compartmentation, osmotic adjustment, overproduction of various types of osmoprotectants (compatible solutes), and induction of antioxidant enzymes (Hasanuzzaman et al. 2013). Osmoprotectants as total soluble sugars TSS, proline protect cells via its role in improving osmotic adjustment, scavenging of increased ROS and protection of membrane structure (Bohnert and Jensen, 1996).

Using of natural and safety compounds is one of the used strategies used to improve salinity tolerance of different plants at different growth stages. One of these compounds is Chitosan. It is a chitin derivative and completely safe for the environment. It is a biopolymer, from carbohydrate family originally formed from glucose ring and have free amino group at carbon number -2 . Chitosan is a bioactive and bio-compatible (Dias et al. 2013). One of important uses of chitosan is using as plant growth promotor (Katiyar et al. 2014) as it improve defense responses in plant under different environmental stresses. Earlier studies from the literature show that, when using chitosan in plants, it increased plant growth and production (Mondal et al. 2012) decrease transpiration (Dzung et al. 2011) and improve different physiological processes thus plants become more tolerant to various stresses (Al-Hetar et al. 2011). In addition, plants treated with chitosan may be less prone to stress evoked by unfavorable conditions (Lizarraga-Pauli et al. 2011, Jabeen and Ahmad, 2013 and Pongprayoon et al. 2013). Chitosan induces important physiological activities of plants on each level of biological organization, from single cells and tissues, via different biochemical processes to changes on the molecular level related to expression of genes (Limpanavech et al. 2008, Hadwiger, 2013 and Nguyen Van et al. 2013).

Thus, this study was conducted to investigate the role of soaking seeds of sunflower plant in various concentrations of chitosan on growth, some physiological parameters, yield and quantity and quality under salinity.

\section{Materials and methods}

A pot experiment was carried out in two successive seasons April 2018 and 2019 in the screen greenhouse of National Research Centre, Dokki, Giza, Egypt, using sunflower (Helianthus annuus L.) cultivar Sakha 53. Seeds of sunflower were obtained from Agricultural Research Centre Giza, Egypt. Chitosan used was supplied from Sigma-Aldrich. Sunflower seeds were soaked for 12 hours in different concentrations of chitosan $(0.0,25,50$, and $75 \mathrm{mg} / \mathrm{L}$, namely, Ch0, Ch1, Ch2, and Ch3) and planted in pots (50 $\mathrm{cm}^{3}$ ) with soil of silt and sand soil with 1:1 ratio to reduce compaction and improve drainage. Seeds were previously sterilized after washing several times with distilled water. The pots were divided into three main groups according to irrigation with different levels of saline solutions by using Stroganov nutrient solutions at $0.0,4000$, and $8000 \mathrm{mg} / \mathrm{L}$ respectively (SO, S1, and S2). Each of the previous groups were divided into four subgroups and soaked in the different concentration of chitosan $(0.0,25,50$, and $75 \mathrm{mg} / \mathrm{L})$. Every treatment consisted of five replicates distributed in a completely randomized design. Sunflower seeds were sown on May in both seasons. Nitrogen fertilizer was applied at a rate of 72 units of $(\mathrm{N}) \mathrm{ha}^{-1}$ and phosphorus fertilizer was applied at a rate of 24 units of (P2O5) $\mathrm{ha}^{-1}$ to each pot. These $\mathrm{N}$ and $\mathrm{P}$ fertilizers were mixed into the soil in each pot immediately before sowing.

Soil field capacity in the pots was estimated by saturating the soil in the pots with water and weighing them after they had drained for $48 \mathrm{hr}$. Field water capacity was 0.36 . Sunflower seedlings were irrigated with equal volumes twice a week of different salt solutions for three times, whereas tap water was used for the fourth one to prevent accumulation of salts around root system. Thinning was carried out at 15 days after sowing, and five plants were left in each pot. Pots of each plot irrigated with one of the following salt concentrations $(0.0,4000$, and $8000 \mathrm{mg} / \mathrm{L}$, namely, S0, S1, and S2). These EC 
concentrations are equal $(0.03,3.2$, and $6.1 \mathrm{dsm}-1)$. The preparation of salt mixture by combined different salts according to Stroganov, 1962 equation as in Table 1.

The component of specific anions and cation in chloride mixture expressed as percentage of total mill equivalents.

\begin{tabular}{llllll}
\hline $\mathrm{Na}^{+}$ & $\mathrm{Mg}^{+2}$ & $\mathrm{Ca}^{+2}$ & $\mathrm{SO}^{-2}$ & $\mathrm{Cl}^{-}$ & $\mathrm{CO}^{-2}$ \\
\hline 38 & 6 & 6 & 5 & 40 & 5 \\
\hline
\end{tabular}

Samples were taken 40 days after sowing to determine the morphological measurements and chemical analysis. One plant per pot were left for yield determination The morphological measurements were shoot length $(\mathrm{cm})$, number of leaves per plant, stem circumference $(\mathrm{cm})$, and fresh and dry weight of shoot (g per plant). Some biochemical aspects were determined as photosynthetic pigments (chlorophyll a, chlorophyll b, carotenoids and total pigments), indole acetic acid (IAA), phenolics, free amino acids, proline, and total soluble sugars. When signs of full maturity stage, measurements for yield and its components were also recorded (head diameter $(\mathrm{cm})$, head circumference $(\mathrm{cm})$, seed yield/plant $(\mathrm{g}), 100$ seeds weights (g), and oil \% and protein\%.

\section{Chemical analysis}

Total chlorophyll a, b and carotenoids contents in fresh leaves were estimated using the method of Lichtenthaler and Buschmann, 2001. Indole acetic acid content were extracted and analysed by the method of Larsen, et al. 1962. Phenolic content was measured as described by Danil and George, 1972. Free amino acid and proline were extracted according to Vartanain et al. 1992, free amino acids were determined with the ninhydrin reagent method (Yemm and Cocking, 1955). Proline content was extracted and calculated according (Bates et al. 1973). Total soluble sugars (TSS) were extracted according to Homme et al. 1992 and assayed according to Yemm and Willis, 1954. The oil content of sunflower seeds was determined according to the procedure reported by A.O.A.C., 1990.

\section{Statistical analysis}

The results will be statistically analyzed using MSTAT-C software. The mean comparisons among treatments will be determined by Duncan's multiple range test at $5 \%$ level of probability (Gomez and Gomez, 1984).

Table 1 The components of the salt mixture used for chloride salinization expressed as \% of the total salt content

\begin{tabular}{lllll}
\hline $\mathrm{MgSO}_{4}$ & $\mathrm{CaSO}_{4}$ & $\mathrm{NaCl}$ & $\mathrm{MgCl}_{2}$ & $\mathrm{CaCO}_{3}$ \\
\hline 10 & 1 & 78 & 2 & 9 \\
\hline
\end{tabular}

\section{Results}

Effect of salt stress, chitosan concentrations, and their interaction on growth indices of sunflower plants

Results of this study presented in (Table 2) showed that increasing salt stress $(4000 \mathrm{mg} / \mathrm{L}$, (S1) slightly increased the studied growth indices (shoot length, number of leaves, stem circumference, fresh and dry weight of shoot) of sunflower plant, as compared with those plants grown under normal irrigation conditions (S0). Meanwhile, increasing salt stress to $8000 \mathrm{mg} / \mathrm{L}$ (S2) reduced the above mentioned parameters, compared with plants irrigated with tap water. However, salt stress affect markedly on different growth characters, but these effects did not reach significant levels (either increasing effect at S1 or decreasing effect at S2). Moreover, the highest values of all studied growth characters were recorded in moderate salt stress S1 $(4000 \mathrm{mg} / \mathrm{L})$.

Meanwhile, soaking sunflower seeds with different concentrations of chitosan (Ch1, Ch2, and Ch3) increased significantly all the studied growth indices comparing with untreated plants (Ch0) (Table 2). Table 2 shows that 50 $\mathrm{mg} / \mathrm{L}$ (Ch2) chitosan was the most effective concentration as it exhibited the highest increases of growth indices, compared to other concentrations.

Regarding to the interaction effect between salt stress with different levels $(0,4000$, and $8000 \mathrm{mg} / \mathrm{L})$ and chitosan different concentration $(0,25,50$, and $75 \mathrm{mg} / \mathrm{L}$ ), Date in Table 2 show that, soaking sunflower seeds with different concentrations not only increased significantly the studied growth indices under normal irrigation water (tap water) but also, could improve these growth indices under various salinity levels (S1 and S2) comparing with their corresponding controls. The highest values of (shoot length, stem circumference fresh weight, and dry weight) was recorded under salt stress $(4000 \mathrm{mg} / \mathrm{L})$ treated with chitosan $(50 \mathrm{mg} / \mathrm{L})$. Meanwhile, the highest value number of leaves was recorded (control salt stress) with chitosan $(50 \mathrm{mg} / \mathrm{L})$. Generally, 50 $\mathrm{mg} / \mathrm{L}$ chitosan was the most effective concentration as compared with the other used concentrations under normal and salt stressed conditions.

\section{Effect of salt stress, chitosan concentrations and their} interactions on photosynthetic pigments content of sunflower Data presented in Fig. 1a proved that, irrigation of sunflower plant with $4000 \mathrm{mg} / \mathrm{L}$ salt water (S1) led to marked and non-significant increases of photosynthetic pigments content (Chlo a, Chllo b, carotenoids, and consequently total pigments) comparing with control plants So (those plants irrigated with tap water). This level of salt water $4000 \mathrm{mg} / \mathrm{L}$ gives the highest values in the 
Table 2 Effect of salt stress (SO, S1, and S2), chitosan concentration (Ch0, Ch1, Ch2, and Ch3) and their interaction on growth characters of sunflower plant (data are means of two seasons)

\begin{tabular}{|c|c|c|c|c|c|c|}
\hline \multicolumn{2}{|c|}{ Treatment } & Shoot length $(\mathrm{cm})$ & No of leaves/plant & Stem Circum $(\mathrm{cm})$ & Fresh weight (gm) & Dry weight (gm) \\
\hline \multicolumn{2}{|l|}{ SO } & 70.07 & 18.08 & 2.48 & 54.23 & 6.74 \\
\hline \multicolumn{2}{|l|}{ S1 } & 74.64 & 18.17 & 2.82 & 59.31 & 7.41 \\
\hline \multicolumn{2}{|l|}{ S2 } & 51.58 & 15.08 & 2.06 & 34.56 & 4.32 \\
\hline \multicolumn{2}{|c|}{ L.S.D } & NS & NS & NS & NS & NS \\
\hline \multicolumn{2}{|c|}{ Control } & 55.42 & 14.89 & 1.87 & 40.74 & 5.09 \\
\hline \multicolumn{2}{|c|}{ Ch1 } & 64.18 & 17.00 & 2.39 & 50.43 & 6.25 \\
\hline \multicolumn{2}{|c|}{ Ch2 } & 72.92 & 19.22 & 2.94 & 56.96 & 7.12 \\
\hline \multicolumn{2}{|c|}{ Ch3 } & 69.23 & 17.33 & 2.60 & 49.34 & 6.17 \\
\hline \multicolumn{2}{|c|}{ L.S.D. at $5 \%$} & 1.45 & 0.63 & 0.1 & 1.45 & 0.22 \\
\hline \multirow[t]{4}{*}{ so } & Cho & 58.07 & 15.33 & 1.8 & 46.47 & 5.81 \\
\hline & Ch1 & 68.63 & 18 & 2.33 & 57.12 & 6.98 \\
\hline & Ch2 & 78.70 & 20.33 & 3.03 & 63.94 & 7.99 \\
\hline & Ch3 & 74.87 & 18.67 & 2.73 & 49.41 & 6.18 \\
\hline \multirow[t]{4}{*}{ S1 } & Cho & 65.27 & 16.67 & 2.17 & 49.22 & 6.15 \\
\hline & Ch1 & 74.00 & 18.33 & 2.73 & 60.2 & 7.56 \\
\hline & Ch2 & 81.33 & 19.67 & 3.37 & 66.41 & 8.3 \\
\hline & Ch3 & 78.07 & 18 & 3 & 61.1 & 7.64 \\
\hline \multirow[t]{4}{*}{ S2 } & Cho & 42.93 & 12.67 & 1.63 & 26.54 & 3.32 \\
\hline & Ch1 & 49.90 & 14.67 & 2.10 & 33.67 & 4.21 \\
\hline & Ch2 & 58.73 & 17.67 & 2.43 & 40.54 & 5.07 \\
\hline & Ch3 & 54.77 & 15.33 & 2.07 & 37.51 & 4.69 \\
\hline \multicolumn{2}{|c|}{ L.S.D. at $5 \%$} & 2.51 & 1.08 & 0.17 & 2.51 & 0.39 \\
\hline
\end{tabular}

photosynthetic pigments content. Meanwhile, increasing salinity stress to $8000 \mathrm{mg} / \mathrm{L}$ (S2) decreased nonsignificantly photosynthetic pigments constituents (Chlo a, Chlo b, carotenoids, and consequently total pigments) compared with control plants.

In contrast, different concentrations of chitosan treatments (Ch1, Ch2, and Ch3) significantly enhanced photosynthetic pigments contents compared with their untreated controls. Chitosan concentration S2 (50 mg/L) gave the highest values of photosynthetic pigments constituents compared to other concentrations (Fig. 1b).

Moreover, the results of interaction between different levels of salt stress and chitosan different concentrations on photosynthetic pigments content of sunflower plant show significant increases either under normal (S0) and stressed conditions (S1 and S2) conditions. However, the highest values were recorded under salt stress S1 (4000 $\mathrm{mg} / \mathrm{L}$ ) and chitosan concentration (50 mg/L) (Fig. 1c).

\section{Effect of salt stress, chitosan concentration, and their interaction on indole acetic acid and phenol of sunflower plant}

Results of this study show that, irrigation of sunflower plant with $4000 \mathrm{mg} / \mathrm{L}$ saline water cause a marked and significant increase in IAA contents comparing with those control plants (Fig. 2). While increasing salinity level to $8000 \mathrm{mg} / \mathrm{L}$ significantly decreased IAA content of sunflower plant as compared with control plants. Moreover irrigation of sunflower plants with saline water significantly increased in phenols content of sunflower comparing with control plants. Phenol contents were significantly increased by salinity and/or external treatment of chitosan. These increases in could alleviate the harmful effect of salinity.

On the other hand, treatment of different concentration of chitosan increased significantly IAA contents and caused more increases in phenol of sunflower plants as compared with untreated contents (Fig. 2). However, the highest content of IAA and phenol contents was recorded by $50 \mathrm{mg} / \mathrm{L}$ concentration.

As for the interaction effect between salt stress and chitosan concentration, date in Fig. 2 showed that, the used levels induced significant increases in IAA and phenol contents under normal irrigation water as well as different salinity levels S1 and S2 (4000 and $8000 \mathrm{mg} / \mathrm{L}$ ). The highest IAA content was recorded in plants under diluted salt stress $(4000 \mathrm{mg} / \mathrm{L})$ treated with chitosan $(50$ $\mathrm{mg} / \mathrm{L})$, meanwhile, the highest value of phenol was recorded in control treatment and chitosan $(50 \mathrm{mg} / \mathrm{L})$. 


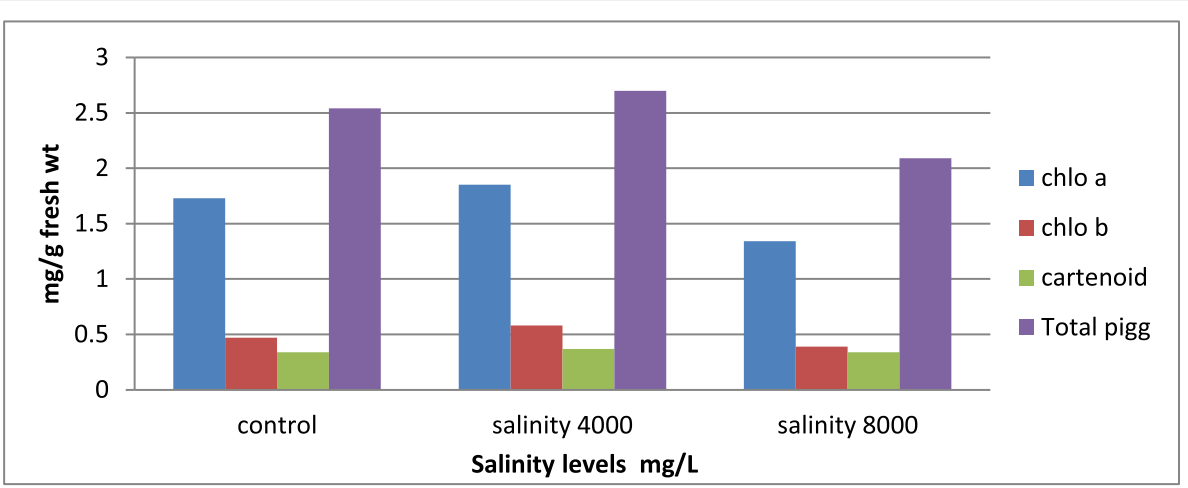

(LSD 5\% Chl. a: NS, Chl. b: NS, Carot.: NS and Total pigments: NS)

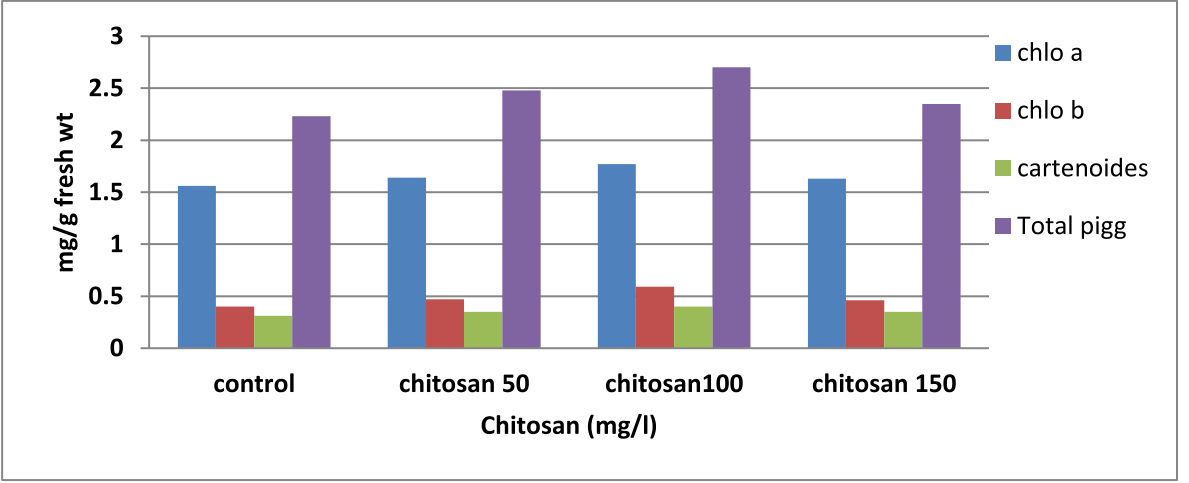

(LSD 5\%: $C h l$ a:0.04, $C h l$ b: 0.02, Carotenoids: 0.05 and Total pigments 0.17)

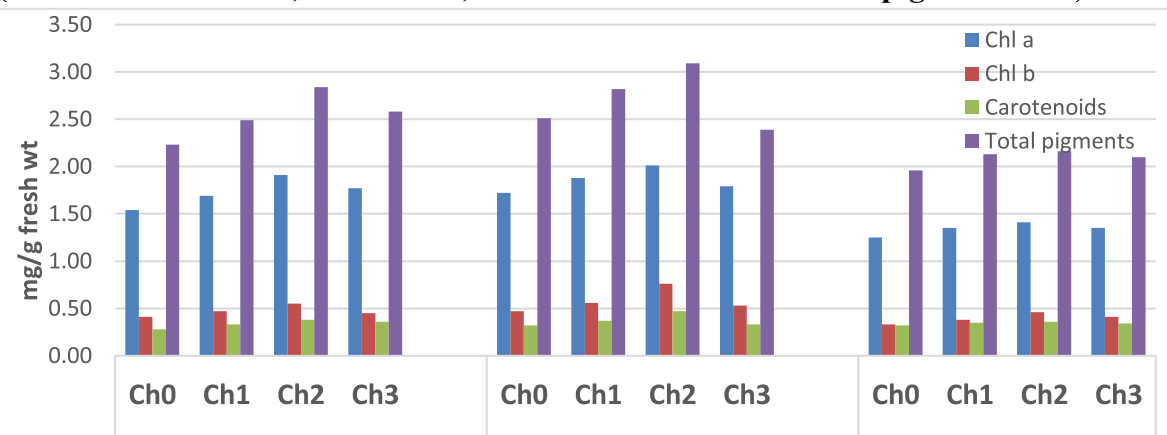

(LSD 5\% Chl. a: 0.07, Chl. b: 0.03, Carotonoids : 0.09 and total pigment 0.29 )

Fig. 1 Effect of salt stress mg/L (SO, S1, and S2), chitosan concentration (ChO, Ch1, Ch2, and Ch3), and their interaction on photosynthetic pigments (mg/g fresh $\mathrm{wt}$ ) of sunflower plant

Effect of salt stress, chitosan concentration, and their interaction on osmoprotectants of sunflower plant

Free amino acid, proline, and total soluble sugars (TSS) contents of sunflower plants were significantly increased in plants irrigated with saline water (S1 $4000 \mathrm{mg} / \mathrm{L}$ and S2 8000 $\mathrm{mg} / \mathrm{L}$ ) (Table 3). Moreover, different applied concentrations of chitosan $(25,50$, and $75 \mathrm{mg} / \mathrm{L})$ treatments significantly increased different studied osmoprotectants of sunflower plant. Fifty milligrams per liter was the most effective treatment.

Moreover, regarding to the interaction effect of salinity stress and chitosan treatment with different concentrations
(Table 3). Different applied concentrations of chitosan (25, 50 , and $75 \mathrm{mg} / \mathrm{L}$ ) treatments significantly increased different studied osmoprotectants of sunflower plant either at normal or salt stress conditions. Fifty milligrams per liter was the most effective treatment.

Effect of salt stress, chitosan concentration, and their interaction on yield, its attributes, oil\%, and protein $\%$ Data presented in Table 4 proved that, increasing salinity levels from 0.0 to 4000 to $8000 \mathrm{mg} / \mathrm{L}$ led to significant reductions in yield and yield attributes of sunflower plant (head diameter, head circumference 


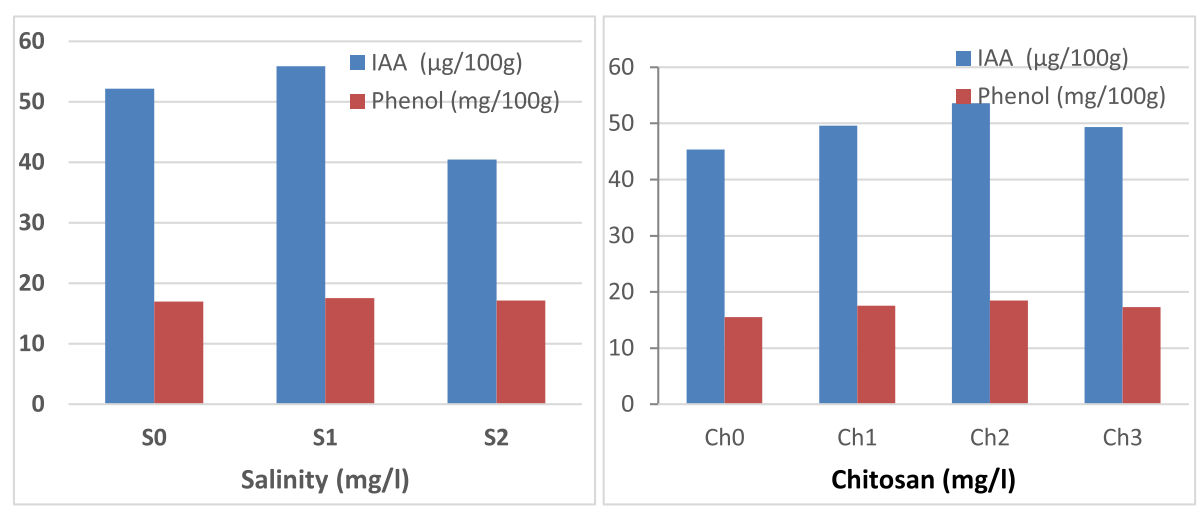
LSD at $5 \%$ for IAA: 1.56
LSD at $5 \%$ for IAA: 1.45
LSD at $5 \%$ for phenol: 1.75
LSD at $5 \%$ for Phenol: 1.75

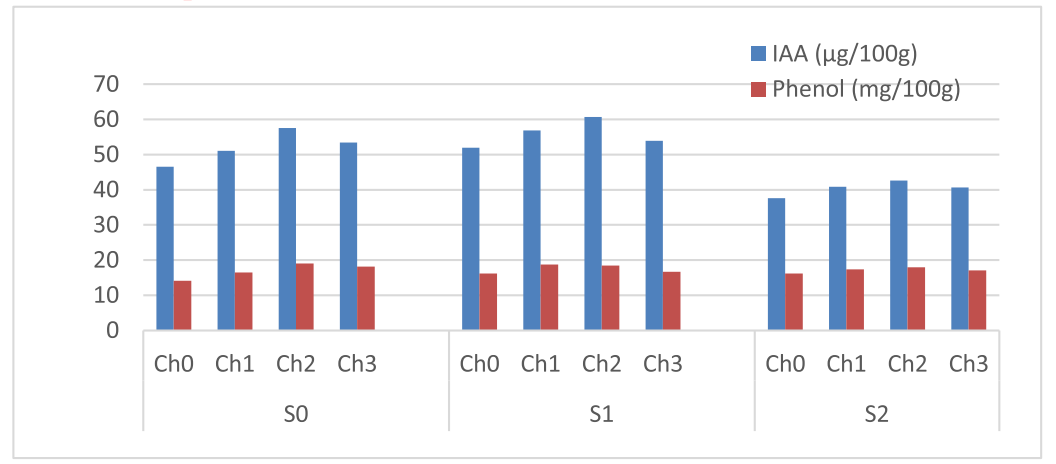

LSD at 5\% for IAA : 1.99, LSD at 5\% for phenol: 2.07

Fig. 2 Effect of salt stress, chitosan concentration and their interaction on indole acetic acid ( $\mu \mathrm{g} / 100 \mathrm{~g})$ and phenol (mg/100 g) contents of sunflower plant

seed yield/plant, 100 seed weight, oil\%, and protein\%) as compared with control plants. All salinity levels had a drastic effect on yield and quality of sunflower. Seed yield per plant was significantly decreased with 8000 $\mathrm{mg} / \mathrm{L}$ salinity level. However, oil\% markedly increased by salinity treatments.

In contrast, different concentration of chitosan $(25,50$, and $75 \mathrm{mg} / \mathrm{L}$ ) significantly enhanced yield and its attributed (Table 4). Moreover, the interaction between salt stress and chitosan concentration on yield, its components, oil\%, and carbohydrate\% caused significant increases in all studied yield attributes as compared with their corresponding controls. However, the highest values of increases were recorded under control plants (those plants irrigated with tap water) with $50 \mathrm{mg} / \mathrm{L}$ chitosan concentration. While the highest value of oil\% was recorded under salt stress $4000 \mathrm{mg} / \mathrm{L}$ with chitosan concentration $50 \mathrm{mg} / \mathrm{L}$ ). Meanwhile, the highest value of protein was recorded under S0 (control salt stress) with chitosan concentration $75 \mathrm{mg} / \mathrm{L}$ (Table 4).

\section{Discussion}

Results of this study presented in Table 2 showed that increasing salt stress $(4000 \mathrm{mg} / \mathrm{L},(\mathrm{S} 1)$ slightly increased the studied growth parameters of sunflower plant. Meanwhile increasing salt stress to $8000 \mathrm{mg} / \mathrm{L}$ reduced those growth parameters. Bakhoum and Sadak, (2016) and Ramaswamy and Seeta, (2018) stated that salinity stress caused marked decreases in growth characters of sunflower plant and they reflected these decreases to metabolic disorders resulted in response to salinity and over production of ROS. In addition, the reductions in shoot length could be due to reduction in cell elongation, cell turgor, cell volume, and eventually cell growth (Banon et al. 2006). Moreover, these decreases in growth indices could be resulted via the effect of high osmotic stress and ion toxicity resulted by over accumulation of sodium and chlorine ions, which induce ionic imbalances thus impair the selectivity of root membranes (Bohra and Dörffling, 1993) or because of variations in cell membrane structure (Sweet et al. 1990).

Meanwhile, soaking sunflower seeds with different concentrations of chitosan increased significantly all the studied growth characters as compared with those untreated plants (Table 2). Recently, earlier investigations confirmed the promoting effect of chitosan on plant growth (Mondal et al. (2012 and 2013) on okra and mungbean, Salachna, and Zawadzińska, (2014) on Freesia 
Table 3 Effect of salt stress, chitosan concentration, and their interaction on osmoprotectants (free amino acids, proline, and TSS) contents of sunflower plant

\begin{tabular}{|c|c|c|c|c|}
\hline \multicolumn{2}{|c|}{ Treatment } & $\begin{array}{l}\text { Free amino acids } \\
(\mathrm{mg} / 100 \mathrm{~g})\end{array}$ & Proline & TSS \\
\hline \multicolumn{2}{|l|}{ so } & 168.98 & 11.96 & 2088 \\
\hline \multicolumn{2}{|l|}{ S1 } & 195.59 & 13.77 & 2405 \\
\hline \multicolumn{2}{|l|}{ S2 } & 236.36 & 16.65 & 2908 \\
\hline \multicolumn{2}{|c|}{ L.S.D at $5 \%$} & 4.65 & 0.75 & 24.32 \\
\hline \multicolumn{2}{|c|}{ Control } & 173.98 & 12.25 & 2139.91 \\
\hline \multicolumn{2}{|c|}{ Ch1 } & 204.99 & 14.44 & 252.34 \\
\hline \multicolumn{2}{|c|}{ Ch2 } & 229.10 & 16.21 & 2831.71 \\
\hline \multicolumn{2}{|c|}{ Ch3 } & 193.28 & 13.61 & 2377.38 \\
\hline \multicolumn{2}{|c|}{ L.S.D. at $5 \%$} & 5.65 & 0.75 & 21.365 \\
\hline \multirow[t]{4}{*}{ SO } & Cho & 124.81 & 8.79 & 1535.10 \\
\hline & Ch1 & 171.96 & 12.11 & 2115.11 \\
\hline & Ch2 & 203.5 & 14.57 & 2544.07 \\
\hline & Ch3 & 175.65 & 12.37 & 2160.50 \\
\hline \multirow[t]{4}{*}{ S1 } & Cho & 184.74 & 13.02 & 2273.35 \\
\hline & Ch1 & 193.75 & 13.64 & 2383.13 \\
\hline & Ch2 & 217.35 & 15.31 & 2673.40 \\
\hline & Ch3 & 186.4 & 13.13 & 2292.72 \\
\hline \multirow[t]{4}{*}{ S2 } & ChO & 212.3 & 14.95 & 2611.29 \\
\hline & Ch1 & 249.25 & 17.55 & 3065.77 \\
\hline & Ch2 & 266.45 & 18.76 & 3277.34 \\
\hline & Ch3 & 217.8 & 15.34 & 2678.93 \\
\hline \multicolumn{2}{|c|}{ L.S.D. at $5 \%$} & 4.89 & 0.44 & 76.72 \\
\hline
\end{tabular}

plant, Sultana, et al. (2017) on tomato and eggplant plants and Rahman, et al. (2018) on strawberry plant). They reflected these increases to the increases in enzymes activities of nitrogen metabolism which increased translocation of nitrogen in the leaves that enhance growth (Chibu and Shibayama, 2003). Chitosan serves as a growth promoting compound which help in increasing water and essential nutrients availability via adjusting cell osmotic pressure and decreasing the over accumulation of toxic free radicals (Guan et al. 2009).

Regarding to photosynthetic pigments, the decreases in photosynthetic pigment components in resulted by salinity stress were in accordance by Ramadan et al. (2019) on sunflower plant, and Sadak (2019) on wheat plant. The reduced effect of salt stress on photosynthesis might be resulted via destruction of photosynthetic pigments and decreased pigment biosynthesis. In addition, these reduced effects could be via increased biosynthesis of proteolytic enzymes as chlorophyllase which is the main reason of the degradation of chlorophyll and/or photosynthetic apparatus damaging (Pandey et al. 2012). Moreover, those reductions are important regulatory steps to decrease absorbance of high light thus decrease the production of ROS (Munne-bosch and Alegre, 2000). The reduced effect of a biotic (stress) stress were resulted by oxidation of photosynthetic pigments and reduced pigment biosynthesis damaging photosynthetic apparatus that leads to decrease in photosynthetic carbon assimilation (Kim et al. 2013).

In contrast, different concentrations of chitosan treatments significantly enhanced photosynthetic pigments contents (Fig. 1b). These improved results might be obtained via improving cytokinin content that stimulated chlorophyll biosynthesis or to the greater availability of amino compounds released from chitosan (Chibu and Shibayama, 2003). Farouk and Amany (2012) stated that, the total content of chlorophylls and carbohydrates of cowpea plant were significantly decreased under water stress; whereas, foliar application of chitosan, significantly increased these parameters. Moreover, Pereira et al. (2017) found that chitosan treatment increased photosynthetic pigments of Phaseolus vulgaris. In another report, Behboudi et al. (2018) foliar treatment of chitosan increased photosynthetic pigments of barley plant.

Moreover, the results of interaction between different levels of salt stress and chitosan different concentrations on photosynthetic pigments content of sunflower plant show significant increases either under normal and stressed conditions (Fig. 1c). These results are in harmony with those obtained by (Munns and Tester, 2008). Chitosan concentration caused a promotive role on $C h l$ a, Chl b, carotenoids, and total pigments. Dzung et al. (2011) confirmed this chitosan stimulating effect on coffee seedlings on increasing content of chlorophylls and carotenoids in comparison to the control. Also, Piotr and Agnieszka, (2014) they found the relative chlorophylls in the freesia increased by chitosan treatment. The increment of chlorophyll content as affected by chitosan application may be caused by plants' enhanced uptake of nutrients, as showed by Nguyen Van et al. (2013).

Results of this study show that, irrigation of sunflower plant with $4000 \mathrm{mg} / \mathrm{L}$ saline water because a marked and significant increase in IAA contents (Fig. 2). While increasing salinity level to $8000 \mathrm{mg} / \mathrm{L}$ decreased significantly IAA content of sunflower plant. Moreover irrigation of sunflower plants with saline water increased phenols content of sunflower. Earlier obtained data of many investigators confirmed the obtained data as Abdelhamid et al. (2013), Jasim et al. (2016), Ramadan et al. (2019), and Sadak and Bakry (2020) on various plants. IAA as a growth regulator stabilize the protective effect of plants towards environmental stress through antagonistic or synergistic interaction with other growth regulators as gibberellic acid, cytokinins and abscicic acid referred as signaling crosstalk (Abass and Mohamed 2011). In 
Table 4 Effect of salt stress, chitosan and their interaction on concentration on yield and its attributes of sunflower plants

\begin{tabular}{|c|c|c|c|c|c|c|c|}
\hline \multicolumn{2}{|c|}{ Treatment } & Head diameter $(\mathrm{cm})$ & Head circum. (cm) & Seed yield/plant(gm) & 100 seed weight $(\mathrm{gm})$ & Oil (\%) & Protein \\
\hline \multicolumn{2}{|l|}{ so } & 9.49 & 29.87 & 22.84 & 5.27 & 23.82 & 15.83 \\
\hline \multicolumn{2}{|l|}{ S1 } & 9.41 & 29.57 & 23.83 & 4.76 & 25.37 & 15.11 \\
\hline \multicolumn{2}{|l|}{ S2 } & 7 & 22 & 18.83 & 3.76 & 24.96 & 13.79 \\
\hline \multicolumn{2}{|c|}{ L.S.D } & 0.38 & 1.03 & NS & NS & NS & NS \\
\hline \multicolumn{2}{|c|}{ Control } & 7.76 & 24.45 & 20.15 & 4.16 & 21.98 & 13.25 \\
\hline \multicolumn{2}{|c|}{ Ch1 } & 8.71 & 27.37 & 19.68 & 4.62 & 25.02 & 14.98 \\
\hline \multicolumn{2}{|c|}{ Ch2 } & 9.24 & 29.05 & 22.8 & 5.01 & 27.01 & 15.62 \\
\hline \multicolumn{2}{|c|}{ Ch3 } & 8.82 & 27.71 & 23.8 & 4.58 & 24.87 & 15.97 \\
\hline \multicolumn{2}{|c|}{ L.S.D. at $5 \%$} & 0.09 & 0.35 & 0.57 & 0.09 & 0.15 & 0.23 \\
\hline \multirow[t]{4}{*}{ SO } & Cho & 8.33 & 26.38 & 17.49 & 4.89 & 20.30 & 13.55 \\
\hline & Ch1 & 9.63 & 30.25 & 21.40 & 5.24 & 23.47 & 15.83 \\
\hline & Ch2 & 10.3 & 32.37 & 26.25 & 5.89 & 26.87 & 16.96 \\
\hline & Ch3 & 9.7 & 30.48 & 26.25 & 5.06 & 24.64 & 16.98 \\
\hline \multirow[t]{4}{*}{ S1 } & Cho & 8.5 & 26.71 & 26.69 & 4.15 & 22.31 & 13.85 \\
\hline & Ch1 & 9.46 & 29.71 & 20.18 & 4.90 & 25.62 & 15.85 \\
\hline & Ch2 & 9.98 & 31.38 & 22.25 & 5.14 & 27.77 & 15.70 \\
\hline & Ch3 & 9.7 & 30.48 & 26.20 & 4.83 & 25.79 & 15.32 \\
\hline \multirow[t]{4}{*}{ S2 } & Cho & 6.45 & 20.27 & 16.30 & 3.45 & 23.32 & 15.55 \\
\hline & Ch1 & 7.05 & 22.15 & 17.45 & 3.71 & 25.95 & 12.33 \\
\hline & Ch2 & 7.04 & 23.41 & 19.89 & 4 & 26.40 & 13.41 \\
\hline & Ch3 & 7.05 & 22.16 & 18.95 & 3.85 & 24.18 & 14.58 \\
\hline \multicolumn{2}{|c|}{ L.S.D. at $5 \%$} & 0.16 & 0.16 & 0.94 & 0.15 & 0.25 & 0.40 \\
\hline
\end{tabular}

addition, these reductions might be due to increasing IAA destruction or decreasing its biosynthesis.

Regarding phenolic contents of sunflower leaves (Fig. 2), phenol contents were increased by salinity and/or chitosan treatment. These increases in could alleviate the toxic effect of salinity. Huang et al. (2005) found that phenol is an antioxidants defense system scavenging over accumulated free radicals.

As for the interaction effect between salt stress and chitosan concentration, date in Fig. 2 showed that, chitosan treatment increased IAA and phenol contents under normal irrigation water as well as different salinity levels. These increases in IAA contents might be due to the induced effect of Chito on auxin-related gene expression, accelerated IAA biosynthesis and transport and reduced IAA oxidase activity increases ( $\mathrm{Li}$ et al. 2019). With respect to phenol contents, phenolic compound are antioxidants which trigger a series of secondary metabolites formed via shikimic acid or malonic acid cycles, as well as it has a cellular signaling functions (Michalak, 2006).

Free amino acid, proline, and total soluble sugars (TSS) contents of sunflower plants were significantly increased in plants irrigated with saline water (Table 3). Increasing the compatible solutes or osmoprotectants (free amino acids, proline, and TSS) enhance cells tolerance to salinity stress through improved osmotic pressure and relative water contents (Tawfik et al. 2017). Also, Hosseini et al. (2014) showed that soluble sugars improve membrane stabilization as they act as ROS scavengers. Proline has an essential role as an osmotic stabilizing as well as stabilization and protection of enzymes, proteins, and membranes (Ashraf and Foolad 2007). The accumulation of proline may be resulted through the increases in its synthesis constantly with inhibition of its catabolism (Anjum et al. 2011). Proline increasing content is an indicator of stress alleviation (El Shintinawy and ELShaubagy, 2001, Saxana et al. 2013, Ahmed et al., 2010 and Hoque et al. 2008).

Increasing salinity levels from led to significant reductions in yield and yield attributes of sunflower plant (Table 4). These reductions could be due to the reductions in growth (Table 2) and photosynthetic pigments contents (Fig. 1) thus decreased the output of photosynthesis (Anjum et al. 2003) and disturb activities of Calvin cycle enzymes (Ashraf and Foolad, 2007). Ramaswamy and Seeta (2018) and Ramadan et al. (2019) found that, salinity stress decreased yield, its components, oil\%, and carbohydrates\% of sunflower plant. Ali et al. (2010) confirmed the changes in seed chemical 
composition which resulted by low water supply during plant life, decreased enzyme activities thus leading to changes in metabolic activities which altered translocation of assimilates to seeds (Abd Elhamid, et al. 2018). Ali and Alqurainy (2006) showed that the main cellular components susceptible to damage by free radicals are lipids, proteins, carbohydrates and nucleic acids. Oil content decreased due to oxidation of some of the polyunsaturated fatty acids (Singh and Sinha, 2005).

In contrast, different concentration of chitosan significantly enhanced yield and its attributed (Table 4). Moreover, the interaction between salt stress and chitosan concentration on yield, its components, oil\%, and carbohydrate\% increased the studied yield attributes. Algam et al. (2010) stated that chitosan improved yield of tomato crop when applied as a soil drench or seed treatment. Chitosan is also reported to significantly increase plant productivity characteristics in chilli (Chookhongkha et al. 2012). Moreover, Khan et al. (2018) confirmed these stimulatory effects of chitosan on pea yield. Chitosan is considered as one of growth regulators and as a signal molecules, as well as its role as a high effective biomolecule (Gornik et al. 2008). The positive role of chitosan on yield resulted by enhancing activities of key enzymes of nitrogen metabolism (nitrate reductase, glutamine synthetase, and protease as well as improving the translocation of nitrogen in the functional leaves thus increased plant growth and development (Sultana, et al. 2017).

\section{Conclusion}

This study highlights the importance of seed treatment with natural compound chitosan especially in salt affected soil. Application of the proper concentration of chitosan could effectively mitigate the hazardous effect of higher salinity levels and improve growth and yield of sunflower under saline sandy soil conditions via improving different physiological aspects.

\section{Acknowledgements}

The authors are thankful to the National Research Centre for the provision of laboratory facilities to carry out this research

\section{Authors' contributions}

Gehan Sh. Bakhoum and Elham A Badr designed and farmed plants, and contributed to the statistical analysis. Mervat Sh. Sadak designed and performed the experiment, and was responsible of all the physiological and biochemical analysis. All authors wrote and reviewed the manuscript. All authors read and approved the final manuscript.

\section{Authors' information}

Gehan Sh Bakhoum is an Assistant Professor of Agronomy, Field Crops Research Dept. at National Research Centre, Egypt.

Mervat Sh. Sadak

Professor of Plant Physiology, Botany Dept. at the National Research Centre, Egypt.

Elham A Badr is a Professor of Agronomy at Field Crops Research Dept. at National Research Centre, Egypt.

\section{Funding}

There are currently no funding sources in the design of the study and collection, analysis and interpretation of data, and in writing of the manuscript.

\section{Availability of data and materials}

The datasets generated and/or analyzed during the current study are included in this published manuscript.

Ethics approval and consent to participate

Not applicable

\section{Consent for publication}

Not applicable

\section{Competing interests}

The authors declare that they have no competing interests.

\section{Author details}

${ }^{1}$ Field Crops Research Department, Agricultural and Biological Research Division, National Research Centre, 33th El Behooth St., P.O. 12622, Giza, Egypt. ${ }^{2}$ Botany Department, Agricultural and Biological Research Division, National Research Centre, 33th El Behooth St., P.O. 12622, Giza, Egypt.

Received: 13 February 2020 Accepted: 20 May 2020

Published online: 27 May 2020

\section{References}

A.O.A.C, 1990. Official Methods of Analysis.20th_edition.Association of Official Analytical Chemists, Arlington, Virginia, U.S.A

Abass SM, Mohamed HM (2011) Alleviation of adverse effects of drought stress on common bean (Phaseolus vulgaris L.) by exogenous application of hydrogen peroxide. Bangladesh J Botany 41:75-83

Abd Elhamid ME, Sadak MS, Tawfik MM (2018) Glutathione treatment alleviate salinity adverse effects on growth, some biochemical aspects, yield quantity and nutritional value of chickpea plant. Sci Fed J Global Warming 2(2):1-11

Abdelhamid MT, Sadak MS, Schmidhalter URS, El-Saady AM (2013) Interactive effects of salinity stress and nicotinamide on physiological and biochemical parameters of faba bean plant. Acta biologica Colombiana 18(3):499-510

Ahmed CB, Rouina BB, Sensoy S, Boukhriss M, Abdullah FB (2010) Exogenous proline effects on photosynthetic performance and antioxidant defense system of young olive tree. J Agricult Food Chem 58(7):4216-4222

Algam S, Xie G, Li B, Yu S, Su T, Larsen J (2010) Effects of Paenibacillus strains and chitosan on plant growth promotion and control of Ralstonia wilt in tomato. J Plant Pathol 92:593-600

Al-Hetar MY, Zainal Abidin MA, Sariah M, Wong MY (2011) Antifungal activity of chitosan against Fusarium oxysporum f. sp. cubense. J Appl Polym Sci 120: 2434-2439

Ali, A. and F. Alqurainy, 2006. Activities of antioxidants in plants under environmental stress. In: Motohashi N (ed.), The lutein-prevention and treatment for diseases. Trans-world Research Network, India PP.187- 256.

Ali Q, Ashraf M, Anwar F (2010) Seed composition and seed oil antioxidant activity of maize under water stress. J Am Oil Chem Soc 87:1179-1187

Anjum F, M Yaseen, E Rasul, A Wahid, S Anjum, 2003. Water stress in barley. I. Effect on chemical composition and chlorophyll content. Pak. J. Agric. Sci., 40: $45-49$.

Anjum SA, Xie XY, Wang LC, Saleem MF, Man C, Lei W (2011) Morphological, physiological and biochemical responses of plants to drought stress. Afr J Agric Res 6(9):2026-2032

Ashraf M, Foolad MR (2007) Roles of glycine betaine and proline in improving plant abiotic stress tolerance. Environ Exp Bot 59:206-216

Bakhoum GSH, Sadak MS (2016) Physiological role of glycine betaine on sunflower (Helianthus annuus L.) plants grown under salinity stress, inter. J. of Chem. Tech. Res. 9(3):158-171

Banon SJ, Ochoa J, Franco JA, Alarcon JJ, Sanchez-Blanco M (2006) Hardening of oleander seedlings by deficit irrigation and low air humidity. Environ Exp Bot 56:36-43

Bates LS, Waldan RP, Teare LD (1973) Rapid determination of free proline under water stress studies. Plant Soil 39:205-207

Behboudi F, Tahmasebi Sarvestani Z, Zaman Kassaee M, Modares Sanavi SAM, Sorooshzadeh A, Ahmadi SB (2018) Evaluation of chitosan nanoparticles 
effects on yield and yield components of barley (Hordeum vulgare L.) under late season drought stress. J Water Environ Nanotechnol 3(1):22-39. https:// doi.org/10.22090/jwent.2018.01.003

Bohnert HJ, RJ Jensen, 1996. Strategies for engineering water stress tolerance in plants. Trends Biotechnol 14(3):89-97. https://doi.org/https://doi.org/10.1016/ 0167-7799 (96)80929-2.

Bohra JS, Dorffling K (1993) Potassium nutrition of rice Oryza sativa L. varieties under $\mathrm{NaCl}$ salinity. Plant Soil 152:299-303

Chibu H, Shibayama H, 2003. Effect of chitosan application on growth of several crops. In chitin and chitosan in life science, Uragami, T.,K. Kurita and T. Fukamizo (Eds).Kodansha Scientific LTd., Japan, ISBN:4-906464-430,pp235-239.

Chookhongkha YN, Miyagawa S, Jirakiattikul Y, Photchanachai S, 2012. Chili growth and seed productivity as affected by chitosan.Proceedings of the International Conference on Agriculture Technology and Food Sciences, Manila, Philippines. Manila, Philippines.

Danil AD, George CM (1972) Peach seed dormancy in relation to endogenous inhibitors and applied growth substances. J Am Soc Hortic Sci 17:621-624

Dias AMA, Cortez AR, Barsan MM, Santos JB, Brett CMA, De Sousa HC (2013) Development of greener multi-responsive chitosan bio-materials doped with biocompatible ammonium ionic liquids. ACS Sustain Chem Eng 1(11):1480-1492

Dzung NA, Khanh VTP, Dzung TT (2011) Re-search on impact of chitosan oligomers on bio-physical characteristics, growth, development and drought resistance of coffee. Carbohydr Polym 84:751-755

El-Shintinawy E, El-Shourbagy MN (2001) Alleviation of changes in protein metabolism in NaCl-stressed wheat seedlings by thiamine. Biol Plant 44(4): $541-545$

FAO, 2000. Global Network on Integrated Soil Management for Sustain-Able Use of Salt-Affected Soils, Rome, Italy, http://www.fao.org/ag/agl/agll/spush.

Farouk S, Amany AR. 2012. Improving growth and yield of cowpea by foliar application of chitosan under water stress. Egypt J Biol 2012;14(1):14-16.

Gomez AK, Gomez AA, 1984. Statistical procedures for Agricultural Research.2nd ed. John Wiley and Sons, New York.

Guan Y, Hu JJ, Wang XJ, Shao CX (2009) Seed priming with chitosan improves maize germination and seeding growth in relation to physiological changes under low temperature stress. J Zhejiang Univ Sci B 10:427-433

Hadwiger LA (2013) Plant science review: multi-ple effects of chitosan on plant systems: solid sci-ence or hype. Plant Sci 208:42-49

Hasanuzzaman M, Hossain MA, Teixeira da Silva JA, Fujita M (2012) Plant responses and tolerance to abiotic oxidative stress: antioxidant defense is a key factor. In: Bandi V, Shanker AK, Shanker C, Mandapaka M (eds) Crop stress and its management: perspectives and strategies. Springer, Berlin, Germany, pp 261-316

Hasanuzzaman M, K Nahar, M. Fujita, 2013. Plant response to salt stress and role of exogenous protectants to mitigate salt induced damages, in Ecophysiology and responses of plants under salt stress, P. Ahmad,M.M. Azooz, and M. N. V. Prasad, Eds., pp. 25-87, Springer, New York, NY,USA.

Homme PM, Gonzalez B, Billard J (1992) Carbohydrate content, frutane and sucrose enzyme activities in roots, stubble and leaves of rye grass (Lolium perenne L.) as affected by sources / link modification after cutting. J Plant Physiol 140:282-291

Hoque MA, Banu MNA, Nakamura Y, Shimoishi Y, Murata Y (2008) Proline and glycinebetaine enhance antioxidant defense and methylglyoxal detoxification systems and reduce $\mathrm{NaCl}$-induced damage in cultured tobacco cells. J Plant Physiol 165(8):813-824

Hosseini SM, Hasanloo T, Mohammadi S (2014) Physiological characteristics, antioxidant enzyme activities, and gene expression in 2 spring canola (Brassica napus, L.) cultivars under drought stress conditions. Turk J Agric For 38:1-8

Huang C, He W, Guo J, Chang X, Su P, Zhang L (2005) Increased sensitivity to salt stress in ascorbate-deficient Arabidopsis mutant. J Exp Bot 56:3041-3049

Jabeen N, Ahmad R (2013) The activity of antioxidant enzymes in response to salt stress in safflower (Carthamus tinctorius L.) and sunflower (Helianthus annuus L.) seedlings raised from seed treated with chitosan. J. Sci. Food Agr 93(7):1699-1705

Jasim AH, WM Abo Al Timmen, AS Abid, 2016. Effect of salt stress on plant growth and free endogenous hormones of primed radish (Raphanus Sativus, L.) seeds with salicylic acid. Int I Chem Tech Res CODEN (USA): 0974-4290. ISSN(Online) 9(06):339-346.
Katiyar D, Hemantaranjan A, Singh B, Bhanu NA (2014) A future perspective in crop protection: chitosan and its oligosaccharides. Adv Plants Agric Res 1:06

Khan R, Manzoor N, Zia A, Ahmad I, Ullah A, Shah SM, Naeem M, Sh A, Khan IH, Zia D, Malik S (2018) Exogenous application of chitosan and humic acid effects on plant growth and yield of pea (Pisum sativum). Inter J Biosci 12(5): 43-50 http://www.innspub.net

Kim JH, Kim KY, Kang EJ, Lee K, Kim JM, Park KT, Shin K, Hyun B, Jeong HJ (2013) Enhancement of photosynthetic carbon assimilation efficiency by phytoplankton in the future coastal ocean. Biogeosciences 10:7525-7535

Larsen P, Harbo A, Klungron S, Ashein TA (1962) On the biosynthesis of some indole compounds in Acetobacter Xylinum. Physiol Plant 15:552-565

Li R, He J, Xie H, Wang W, Bose S, Sun Y, Hu J, Yin H (2019) Effects of chitosan nanoparticles on seed germination and seedling growth of wheat (Triticum aestivum L.). Inter J Biol Macromol 126:91-100. https://doi.org/10.1016/j. ijbiomac.2018.12.118

Lichtenthaler HK, Buschmann C (2001) Chlorophylls and carotenoids: measurement and characterization by UV-VIS spectroscopy. In: Wrolstad RE, Acree TE, An H, Decker EA, Penner MH, Reid DS, Schwartz SJ, Shoemaker CF, Sporns P (eds) Current protocols in food analytical chemistry (CPFA). Wiley, New York, pp: F4.3.1-F4.3.8.

Limpanavech P, Chaiyasuta S, Vongpromek R, Pichyangkura R, Khunwasi C, Chadchawan S, Lotrakul P, Bunjongrat R, Chaidee A, Bangyeekhun T (2008) Chitosan effects on floral production, gene expression, and anatomical changes in the Dendrobium orchid. Sci Hortic 116(1):65-72

Lizarraga-Pauli EG, Torres-Pacheco I, Moreno Martinez E, Miranda-Castro SP (2011) Chitosan application in maize (Zea mays) to counteract the effects of abiotic stress at seedling level. Afr J Biotechnol 10(34):6439-6446

Mahajan S, Tuteja N (2005) Cold, salinity and drought stresses: an overview. Arch Biochem Biophys 444(2):139-158

Manchanda G, Garg N (2008) Salinity and its effects on the functional biology of legumes. Acta Physiol Plant 30(5):595-618

Michalak A (2006) Phenolic compounds and their antioxidant activity in plants growing under heavy metal stress. Plant Cell 15:523-530 CrossRef

Mondal MMA, Malek MA, Puteh AB, Ismail MR, Ashrafuzzaman M, Naher L (2012) Effect of foliar application of chitosan on growth and yield in okra. Aust J Crop 6:918-921

Munné-Bosch S, Alegre L (2000) The xanthophyll cycle is induced by light irrespective of water status in field-grown lavender (Lavandulastoechas) plants. Physiol Plant 108:147-151

Munns R, 2005. Genes and salt tolerance: bringing them together,"New Phytologist, 167 (3): 645-663.

Munns R, Tester M (2008) Mechanisms of salinity tolerance. Annu Rev Plant Biol 59:651-681

Nguyen Van S, Dinh Minh H, Nguyen Anh D (2013) Study on chitosan nanoparticles on biophysical char-acteristics and growth of Robusta coffee in green house. Biocatal Agric Biotechnol 2(4):289-294

Pandey HC, Baig MJ, Bhatt RK (2012) Effect of moisture stress on chlorophyll accumulation and nitrate reductase activity at vegetative and flowering stage in Avena species. Agric Sci Res J 2:111-118

Pereira AS, Silva PM, Olivera JL, Olivera HC, Fraceto LF (2017) Chitosan nanoparticles as carrier systems for the plant growth hormone gibbereillic acid. Collodis and Surfaces B: Bioenterfaces 150:141-152

Piotr S, Agnieszka Z (2014) Effect of chitosan on plant growth, flowering and corms yield of potted freesia. J Ecol Eng 15(3):97-102

Pitman MG, Läuchli A, 2002. Global impact of salinity and agricultural ecosystem," in Salinity: Environment—Plants—Molecules, A. L"auchli and U. L"uttge, Eds., pp. 3-20, KluwerAcademic, Dodrecht, The Netherlands.

Pongprayoon W, Roytrakul S, Pichayangkura R, Chadchawan S (2013) The role of hydrogen peroxide in chitosan-induced resistance to osmotic stress in rice (Oryza sativa L.). Plant Growth Regul 70(2):159-173

Rahman M, JA Mukta, AA Sabir, DR Gupta, M Mohi-Ud-Din, M Hasanuzzaman, et al. 2018. Chitosan biopolymer promotes yield and stimulates accumulation of antioxidants in strawberry fruit. PLoS One 13(9): e0203769. https://doi.org/ https://doi.org/10.1371/journal.pone.0203769.

Ramadan AA, EM Abd Elhamid and Sadak MS, 2019. Comparative study for the effect of arginine and sodium nitroprusside on sunflower plants grown under salinity stress conditions. Bull Natl Res Centre 43:118. https://doi.org/ https://doi.org/10.1186/s42269-019-0156-0

Ramaswamy A, Seeta RRS (2018) Effect of salinity stress on seedling growth of sunflower (Helianthus annuus L.) genotypes. Inter J of Biol Res 3(1):70-75 
Sadak MS 2019. Physiological role of trehalose on enhancing salinity tolerance of wheat plant. Bull National Research Centre $43: 38$ https://doi.org/https://doi. org/10.1186/s42269-019-0077-y

Sadak Mervat Sh, Bakry A Bakry, 2020. Alleviation of drought stress by melatonin foliar treatment on two flax varieties under sandy soil, Physiol Mol Biol Plants 26(5):907-919.https://doi.org/https://doi.org/10.1007/s12298-020-00789-z

Salachna P, Zawadzińska A (2014) Effect of chitosan on plant growth, flowering and corms yield of potted freesia. J Eco Eng 15(3):97-102. https://doi.org/10. $12911 / 22998993.1110223$

Saxena SC, Kaur H, Verma P et al (2013) Osmoprotectants: potential for crop improvement under adverse conditions. In: PlantAcclimation to environmental stress. Springer, New York, NY, USA, pp 197-232

Singh S, Sinha S (2005) Accumulation of metals and its effects in Brassica juncea (L.) Czern. (cv. Rohini) grown on various amendments of tannery waste. Ecotoxicol Environment Safe Orlando 62:118-127

Stroganov BP, 1962 Physiological basis of the salt tolerance of plants (under different types of soil salinization). Izd. Akad. Nauk. USSR, Moscow.

Sultana S, Islam M, Khatun A, Hassain A, Huque R (2017) Effect of foliar application of oligo-chitosan on growth, yield and quality of tomato and eggplant. Asian J Agric Res 11(2):36-42. https://doi.org/10.3923/ajar.2017.36.42

Sweet WJ, Morrison JC, Labaritch JM, Matthews MA (1990) Altered synthesis and composition of cell wall of grapevines Vitis vinifera L. during expression and growth inhibiting water deficits. Plant Cell Physiol 31:407-414

Tawfik MM, Badr EA, Ibrahim OM, Abd Elhamid EM, Sadak MS (2017) Biomass and some physiological aspects of Spartina patens grown under salt affected environment in South Sinai, inter. J Agric Res 12(1):17-26

Vartainan N, Hervochon P, Marcotte L, Larher F (1992) Proline accumulation during drought rhizogenesis in Brassica napus var. Oleifera Plant Physiol 140: 623-628

Yemm EW, Cocking EC (1955) The determination of amino acids with ninhydrin. Analyst. 80:209-213

Yemm EW, Willis AJ (1954) The respiration of barley plants. IX The metabolism of roots during assimilation of nitrogen New Phytotol 55:229-234

\section{Publisher's Note}

Springer Nature remains neutral with regard to jurisdictional claims in published maps and institutional affiliations.

\section{Submit your manuscript to a SpringerOpen ${ }^{\circ}$ journal and benefit from:}

- Convenient online submission

- Rigorous peer review

- Open access: articles freely available online

- High visibility within the field

- Retaining the copyright to your article

Submit your next manuscript at $\boldsymbol{\nabla}$ springeropen.com 